\title{
SUCCESSION PLANNING AND PASSING ON LEADERSHIP - APPROACHES FOR LIBRARY ASSOCIATIONS
}

\author{
Blanche Woolls \\ Professor Emerita, San Jose State University, bwoolls@slis.sjsu.edu
}

\begin{abstract}
Succession planning is relatively new to professionals in the library and information science profession and even newer when applied to library associations. Little can be found in the literature, so we must borrow from the business, education, and health professions while designing our own models. How we identify potential leaders early in their careers, nurture them, and give them opportunities to practice leadership can be a major benefit to members of library associations. This article attempts to explain succession planning and to show its relationship to officers and leaders in library associations.
\end{abstract}

\section{INTRODUCTION}

Few would argue that for organizations and associations to thrive, they must have good leadership. According to Geroy, Caleb, and Wright, "every profession or discipline along with its representative organizations, is challenged to pass along the critical skills and normative elements of its culture, content, and process in order to ensure its survival." ${ }^{\text {(p25) }}$ Recently, the keywords for passing along these skills have been succession planning, a term coined in the early part of the $20^{\text {th }}$ century by Henri Fayol. ${ }^{1\left({ }^{(p 27)}\right.}$ Following his fourteen management points could ensure that the tenure of personnel in business organizations remains stable. ${ }^{2}$ After some time, the members of the education and the health professions began adopting succession plans to solve their problems when it came time for new leadership to assume their roles.

In the education world, the succession of administrators has become critical for school districts experiencing frequent changes in superintendents and principals. One of their approaches to succession planning is termed leadership forecasting, "...the proactive development and selection of school administrators.... starts with the end in mind by considering future vacancies, both known and unknown."” Such planning means that positions would be filled with outsiders or insiders who were prepared and ready for a promotion rather than the opposite. This planning also has the better financial outcome of hiring the right people who were ready for the challenge rather than adding the cost of replacing someone who was inadequate in the position. Fallout from poor appointments included "lower productivity and morale among staff, unhappy parents, a tarnished school reputation, political 
or legal mistakes that warrant repair by others and additional stress and work for supervisors trying to fix problems.",

Librarians are now talking about succession planning in preparing for changes in management, but it is still in the beginning stages. Little can be found in the literature. In a search for recent articles in one database, over 200 citations were found for succession planning, but only two were in library periodicals, both in periodicals concerning library finances. The literature, whether from business, education, health, or libraries, focuses on the need for developing leadership skills in those who will be our successors, so that succession planning can prevent the obstacles described below by Hart can be minimized:

Succession is a disruptive event that changes the line of communication and relationships of power, effects decision making, and generally disturbs the equilibrium of normal activities. During the succession period, relationships are formed and negotiated, expectations between parties are confirmed or disconfirmed, conflicts may be confronted and resolved, and new leaders are accommodated or not in their work role and the new environment. ${ }^{4}$

In order to minimize the conflicts which could occur with unplanned succession, developing leaders to take over new roles means leader librarians should be in search of their successors. Up to a point, you can influence the selection; but we must recognize in many situations you will not get to pick your successor. In associations they may be elected; however this does not release us from the need to help find successors.

\section{LIBRARIANS AS LEADERS IN SEARCH OF SUCCESSORS}

Identifying potential library leaders in the profession has been aided in those organizations whose members have held institutes and workshops to prepare new graduates and new hires with the skills and the ambition to seek leadership roles as they gain experience. The first, Snowbird, was initiated by the American Library Association (ALA) President, Margaret Chisholm, who included in her vision the development of a leadership plan for the association. Her appointed committee's plan was to write a proposal for funding to hold a training institute. With the help of a public library director, Dennis Day, funding was granted by a vendor, and the institutes were established. Library school faculty and employers were asked to nominate potential leaders from their recent graduates and new employees. The week's training was led by acknowledged leaders in the field. Other institutes have followed a similar pattern.

State library associations have held or are holding leadership institutes for their members. In 2000-2002, the Stanford-California State Library Institute on $21^{\text {st }}$ Century Leadership held three leadership institutes on the Stanford University campus. Planned for 150 delegates, 2/3 came from all types of libraries within the 
state and $1 / 3$ came from other states and countries. These were designed to help answer the questions, "How are librarians preparing their organizations to survive and take advantage of escalating changes in information technology?" and "How does the profession identify and develop its next generation of leaders?"

The Texas Library Association (TLA) plans its annual sessions for five day institutes to train "Tall Texans." Key people from around the state and an outside facilitator conduct the training and serve as mentors. TLA units and employers of participants make funds available to help defray costs for attendance. A two-year commitment to a Personal Action Agenda is a requirement of attendance.

The Frye Institute, sponsored by Emory University and the Council on Library and Information Resources, is available for potential leaders in higher education who are nominated by a senior institutional officer who also makes an institutional commitment to the recipient. Fifty to sixty participants attend a two-week session, plan a year-long practicum project, and then attend a follow-up summary experience at the end of the year.

Harvard's Leadership Institute for Academic Librarians, in collaboration with a division of ALA, the Association for College and Research Libraries, hopes to increase the participants' capacity to "lead and manage." The program stresses the characteristics of effective leadership, addresses transformational learning, the roles and responsibilities in planning initiatives, and organizational strategies and change. Both of these last two institutes are more expensive for participants.

Canada's Northern Exposure in Leadership Institute has been sponsored over the past ten years by the University of Alberta. Held every two years, it is designed "to assist professional librarians to develop, strengthen and exercise their leadership skills so that they may be better equipped to formulate, articulate and achieve the future changes required by libraries into the $21^{\text {st }}$ century." Participants are nominated by employers, library schools, and library associations for their leadership potential, excellent communication skills, accomplishment in academic performance, and successful employment experience.

Another leadership program sponsored by ALA was launched to encourage minorities to enter the library profession. The $\$ 5,000$ Spectrum scholarships are allocated for tuition for the Master of Library and Information Science degree, and the program has since been expanded for doctoral degrees. Many library schools offer additional funding through scholarships and graduate assistantships for further support. Throughout the year Spectrum Scholars are provided many opportunities to network with each other and with library leaders through electronic discussion lists. Funding for travel and lodging is provided for Scholars to attend the Spectrum Leadership Institute at the completion of their first year of study.

All of these efforts have been planned primarily to develop leaders for the workplace, although training provided by ALA also aims to prepare future association leaders. ALA training can help individuals to lead other associations as well. 


\section{ARE YOU AND YOUR ASSOCIATION READY TO ENTICE NEW LEADERS?}

The next task is to decide if your association is ready to entice new leaders. One of the best ways to get started on the leadership path is to become a member or to chair a committee within an association. Association members who are in the position to make such appointments must feel comfortable in making these assignments. The author of this article is well aware of one particular section of one large association whose leadership was so reluctant to add new members to any position within their association that many potential leader members moved to another related section and dropped their previous membership. Your association members must understand the need to recruit new members, to recognize and identify their leadership potential, and to help them realize their ambitions. Only then is it time to look for those future leaders.

\section{Identifying potential leaders}

Faculty members in many schools of library and information science actively encourage their students to become members of professional associations and many of these associations have a student membership rate that is much less than regular membership. Students are also encouraged to attend professional meetings. This is usually more successful in a state association because the students might be able to afford the cost to attend rather than a national association which meets at longer distances with more costly travel and higher registration fees. If students are able to attend while they are students, they are usually good candidates to move into an active role when they graduate. Their finding funding to attend usually signals a true interest in the profession and the association. When students seem to have leadership qualities, their professors can offer some analysis of the student's desire and ability to start honing their leadership skills. When a professor brings students to the attention of the elected officers, it is usually an endorsement that these persons will be excellent members to target for attention once the student is employed.

Many students are able to fit a practicum or internship into their programs, and the employees with whom they work should also be able to discuss the potential leadership attributes of those under their supervision and can offer references. In some cases, the supervisor will take the student to department meetings within their institutions or ask them to go to local meetings outside the library. How these students go about networking at such events provides a clue to their communication skills and their leadership potential.

Newly elected leaders of associations have the most potential to place members in leadership roles. At the same time that they are setting goals for their tenure in their positions, they need to be made aware of the need to recruit and mentor these future leaders. Identifying leaders goes beyond asking friends and acquaintances, 
past professors and employers for names; it means identifying the qualities the association needs. "Desire, interest, and willingness need to be at the top of the list of desirable traits." Richards also adds warmth and sincerity about your association's purpose. He then suggests the candidate needs to be both capable and a selfstarter with sufficient background knowledge and with good communication skills. Obviously one needs someone who will contribute to the association who, with appropriate orientation and training, can become essential.

Succession planning is an integral part of this process. Analyzing what the association will need in the immediate and long-term future are all aspects of this. Some questions to answer include the following. Do you need

- a creative thinker who can propose solutions to problems?

- a good fund raiser or maybe someone with personal wealth or corporate connections to help fund projects?

- a charismatic person to encourage an increase in membership?

- a person who represents a particular segment of the membership who will help balance the leadership team?

- a good lobbyist to talk with persons in leadership positions in the corporate world, government officials, other library administrators?

- a good representative to talk to the media about your association?

You need to be able to put any personal biases aside so that you can invite the "best and the brightest" who are the most likely to move your association forward. "An effective organization needs leaders who are mature and able to make sound decisions. They must also be able to weather the inevitable storms and deal with problems."7 Once you have identified potential leaders, you should try to analyze their leadership styles.

\section{Where do they fit: identifying their leadership styles}

Many books have been written about leadership styles, noting that no person has one style consistently. However, a person is more likely to act one way most often. To act inconsistently from one's usual style will confuse followers. When a dictator stops dictating and asks the group for advice on how to move forward, most in the group will be reluctant to offer suggestions, thinking it is wasted effort.

Blake and Mouton ${ }^{8}$ are favorites of mine. Their five styles are:

- Country Club: This leader gives thoughtful attention to people so that one has a friendly, comfortable team. The ultimate project may suffer if the steps to completion seem to act against the team's sense of ease with the situation.

- Impoverished: It is very difficult to consider people with these attributes as a leader because they care little for their co-workers or the task at hand. This leader's view is to exert minimal effort to accomplish a task with little care about the happiness of those in the workforce. 
- Team: The team leader generates interdependence though a common stake in the outcome. Team members are committed to the project and there is a general sense of trust and respect.

- Organization: While this leader balances the workload with some attention to the morale of people, the ultimate goal is to accomplish the task.

- Authority, Obedience. These leaders might be described as dictators and their attitude is one of certainty that the path they have chosen is the best possible. Others involved should not interfere but should just carry out the plan as outlined.

When you discover in what role your potential leaders feel most comfortable, assign them to those leadership roles for their first assignments. Those who like to have everyone around them happy won't want to work on a plan to restructure the association, abolish committees, and reduce the size of the association's board and voting council. The organization person's vision might be the best plan, but it would take the team leader to sell it. The impoverished leader would not care if it did or did not happen and the dictator would upset those who did not agree.

Identifying leadership style is but one of several aspects in the evolution of new leaders. Most authors today say that a key component for success in developing new leaders is mentoring. One author believes "it takes a mentor to challenge leaders, prod them, and help them marshal the courage, energy and self-trust needed to meet the call's demanding dimensions. Without a mentor's help, few leaders would understand what they are capable of accomplishing." ${ }^{9}$ We do all stand "on the shoulders of giants."

\section{"On the shoulders of giants"}

Most attribute this phrase to Isaac Newton who used it in a letter to Robert Hooke in 1676 to whom he wrote, "If I have seen a little further, it is by standing on the shoulders of Giants." In fact, an earlier use was by a $12^{\text {th }}$ century theologian and author, John of Salisbury who wrote, "We are like dwarfs sitting on the shoulders of giants. We see more, and things that are more distant than they did, not because our sight is superior or because we are taller than they, but because they raise us up, and by their good stature add to ours." ${ }^{10}$ It is our responsibility in succession planning and leadership identification to serve as mentors to our aspiring leaders. The goal of mentoring is to foster leadership development within the profession and the association. It offers opportunities for learning beyond on-the-job experiences. While a great deal of responsibility falls upon the mentor, much can be learned from the mentee. It is a form of continuing education for both and it requires energy and commitment from both.

One of the things that an association might offer is a training program for its mentors to help them understand how they will pass along their knowledge, and the knowledge of others. Because mentoring does take some time commitment, potential mentors must decide how the want to work with mentees. It can be in a 
truly casual relationship where the mentee should feel free to call the mentor with questions. At the other end of the spectrum is the mentor who helps the mentee to develop the plan for moving into a leadership role. One mentor reported that, as an unexpected surprise, that most of his time was spent "talking about leadership, people skills, and relationships."11

He also discovered that many times, if he asked the mentee what he nor she would do to solve a particular problem, the answer was exactly what he would have suggested and that his role seemed to be "validation that the mentee is headed down the right path."

Mentors can be very helpful in identifying when a new leader is ready to take a leadership role and what that role should be. They will also be helpful in convincing the potential leader to accept the appointment.

\section{Convincing them to lead}

Succession planning will fail if potential leaders refuse to accept leadership roles. To convince them, it is always best to make an offer that can't be refused. The trick is to make a good analysis of where exactly they are in their professional careers so that the offer does not conflict with their day job. To ask a college professor to take on a major role when they are working night and day to prepare their dossiers for tenure review would not be good timing. On the other hand, someone who is tenured but wishes for a promotion to full professor might be delighted to take on a much higher level of leadership. Persons who have recently been given a promotion to a higher level in their positions will be learning that role and trying to cope with the accompanying stress will not wish to add to that stress, whereas someone who has been in a position for some time may be looking for some new challenge.

When the timing is right, the person who moves into leadership within the association will be entering an era of professional development and continuing education. Their new position will help them learn, and it will provide them the opportunity to encourage the professional development of others in the association. Succession planning means providing opportunities for leadership experience.

\section{PROVIDING LEADERSHIP EXPERIENCE}

Training new talent in the workplace can be an expensive investment and it may be less favored than an investment in upgrading technology. It may be that the professional librarian is not being given much leadership experience in the workplace and will welcome this within the association. Leadership takes many forms: internships within committees, committee membership, chairing committees, holding elected office, and managing projects. Deciding which direction is best for an appointment requires a careful analysis of management style, which offer will 
be most difficult to refuse, and the fit of the person to the position. Once the leadership experience is successful, it is important that this leader's qualities be shared with the wider world.

\section{Making the world aware of their leadership potential}

One way veterans in our profession can help young people take on leadership roles is to make the world around them aware of their leadership potential. This is more than introducing them to important members of the association at a yearly conference; it is the act of helping them with those activities which will increase their visibility.

\section{Helping them pass along their knowledge}

One library school dean in my early years as an assistant professor made sure that I had invitations to speak at conferences and to contribute articles to journals. He believed that getting proposals funded from outside agencies not only brought attention to the school, but provided a venue for practical research applications. When he was asked to edit a book on school librarianship, he invited me to write a chapter. In every case, it allowed me to share my knowledge with a wide audience.

\section{Conference presentations}

Getting on a conference program is often a challenge for budding leaders. Some conference planners are reluctant to ask speakers to present if they have no track record. Your endorsement of the expertise of the potential speaker can go a long way in getting them on the program. You can then help them with their presentation by reviewing their papers or their plans for presenting their information so that it will be interesting to the audience. If good communication skills are the mark of a great leader, helping them speak before an audience is a good part of those skills.

\section{Professional writing: research based and practical}

Many students think that their diploma means they will never write another paper or conduct any more research. Perhaps helping them set this misconception aside is a first step. Perhaps having them co-author something will help them get started also. Because of the tenure and promotion issues related to life in academic communities, many faculty members need to conduct research and publish in refereed journals. As an association member, it would be helpful to share the task by helping find persons within the association who have a population the researcher needs so that the researcher can conduct the research. At other times, if the association needs data collected and analyzed, you budding leader might be encouraged to undertake this for the association. 
Many professional journals publish thought pieces that will address trends and issues in the profession. If a potential leader is able to write about a practical solution to a critical problem, it is another way to gain name recognition in the wider community and also demonstrate the ability to solve problems. Writing a professional book is a more difficult challenge because it requires more attention to detail and usually requires a much greater time commitment. However, as one dean did for his emerging leaders, if you are editing a book, you can have chapters written not only by recognized experts in the field, but also by some budding experts.

\section{New technology opportunities}

Technology offers many opportunities for emerging leaders to demonstrate their leadership skills within an association. They can be useful in helping the association membership who may be less interested move forward to use more sophisticated technologies. They can design online surveys to discover what the membership really wants. It could be they can suggest new ways to vote at council meetings and membership meetings, saving both paper and time.

\section{CONCLUSION}

Succession planning as strategic planning for the association ensures that new leadership is ready to take over when others step down. The leaders-in-waiting have been well initiated by their mentors from the association membership. They have been given opportunities to practice leadership. In the end, your association thrives because it has excellent new leadership to continue the mission of the association for years to come. Your new leaders recognize that they are demonstrating their skills and accomplishments. Finally, the real winner will be your satisfaction in knowing that you have set these prospects on the right path, because you have raised them up, and by your good stature you and your association have added to theirs.

\section{REFERENCES}

1. Geroy, GD, Caleb D, Wright PC. Understanding and articulating effective succession planning: a means for infusing influences by NAITTE. Journal of Industrial Teacher Education 2005;42(1):24-40.

2. Fayolism. http://en.wikipedia.org/wiki/Henri_Fayol_and the_Administrative theory\#The_14_Principles_of_Administration (accessed 9 May 2009).

3. Lovely S. Leadership forecasting. Leadership 2004;34(1):17-9. http://find articles.com/p/articles/mi_m0HUL/is_1_34/ai_n6358519/pg_2/ (accessed 10 May 2009). 
4. Hart AW. Leader succession and socialization: a synthesis. Review of Educational Research 1991;61:451-74

5. Northern Exposure to Leadership. 28 Sept 2008. http://www.ls.ualberta.ca/ neli/pressrelease.html (accessed 10 May 2009).

6. Richards RR. Lending a hand to the leaders of tomorrow. Association Management 1997;49 (January):35-7.

7. Rothwell WJ. Effective succession planning. $3^{\text {rd }}$ ed. New York: American Management Association. 2005. p18-9.

8. Blake RR, Mouton J S. Managerial grid III: the key to leadership excellence. Houston, TX: Gulf Publishing Company, 1985.

9. Shenkman M. Born to be recognized. Training 2005;42(1):42.

10. The Phrase Finder http://www.phrases.org.uk/meanings/268025.html (accessed 10 May 2009).

11. Whitten N. Leaders are teachers, too. PM Network 2008;22(8):24-5. 